\title{
Industrial traumatism management oriented to result
}

\author{
V.S. Parshina ${ }^{1}$, T.B. Maruschak ${ }^{1, *}$, and A.A. Gusev ${ }^{1}$ \\ ${ }^{1}$ Chair "Management in social and economic systems", Ural State University of Railway Transport (USURT), Yekaterinburg, Russia
}

\begin{abstract}
To improve industrial traumatism management we should direct at the analysis of the causes of the employee's dangerous actions and elaboration of the measures to minimize the identified causes on an employee. The specific aim of managing the system of safe labour is to prevent the reduction of the activity effectiveness that comes from falling of capacity, diseases, traumas and employees death. The condition for the successful realization of the management decision is specifying of goals concerning the certain structural subdivision, its quantitative expression, methods of achievement, the involved functions. On the basis of the study of the modern psychological and normative theories of decision-making proposed is the technology of work with administrative decisions including the elaboration stage, making and acceptance of decisions. This technology is aimed at minimization of risks related to the accident rate and traumatism.
\end{abstract}

\section{Introduction}

Management of the industrial traumatism level is aimed to ensuring efficiency of activity through optimization of expenses to ensure safety and gain maximum economic effect from reducing the accident rate. The system of industrial traumatism management that has been existing in this country for long years was oriented to the observance of the formulated requirements and did not raise issues related to the end-point in this sphere. Perfection of the management system in market conditions allows to obtain an additional effect. We will consider the aspects of industrial traumatism management basing on our research in structural subdivisions of railway and time-tested experience of the developed countries.

\section{Management of the industrial traumatism}

To show the ability of the designated management processes we will refer to the statistical data generalized by Henrikh. The essence is in a stable dependence of severe injuries with everyday violations. The author shows quantitative correlation of fatal, severe and easy cases of industrial traumatism (Fig. 1). The frequency of injuries depends on the amount of dangerous action, as can be seen from the figure. Using this principle we can conclude that industrial traumatism can be controlled.

The identified proportions depend on the nature of production and the principle has not been refuted for the past years. The statistical study of the traumatism on the railway structural subdivisions allows the identification of certain correlations. Presented in [1] calculations based on 18 railways show that there is a middle correlation degree of the general coefficient of production accidents frequency in the workplace and the coefficient of industrial accident with the fatal industrial end. The questioning revealed that not all mortal accidents were subject to investigation, cases resulting in an error. That is, the objective assessment of industrial traumatism state allows to approximate to the proportions derived by Henrikh. The study of the abovementioned coefficient dynamics on the concrete railway and the experience of the leading structural subdivisions will provide an informative base for administrative decisions.

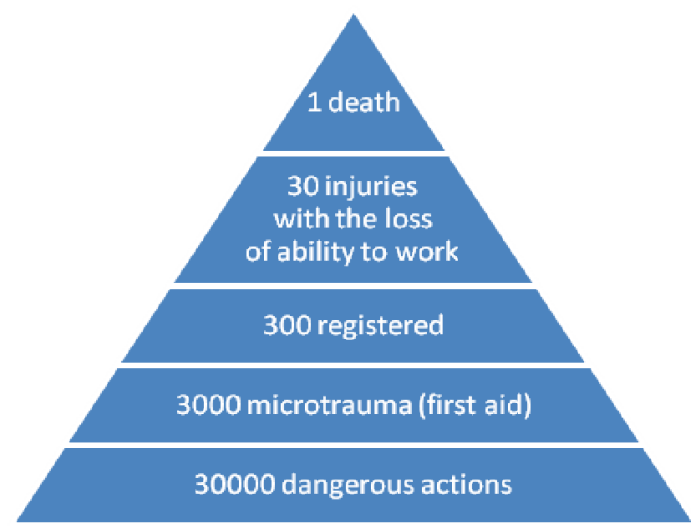

Fig. 1. Henrikh,s pyramid of accidents.

To improve industrial traumatism management we should direct at the analysis of the causes of the employee's dangerous actions and elaboration of the measures to minimize the identified causes on an employee. In the table 1 we reduce the most common reasons of an employee's dangerous actions grouped according to Methodology [2] and suggest appropriate management tools. The same function lie in the basis of management of the industrial traumatism that are in managing of organizational and technical systems defined in the control theory.

\footnotetext{
Corresponding author: tbmar@mail.ru
} 
Table 1. The main groups of causes of employees, dangerous actions and the proposed management.

\begin{tabular}{|c|c|c|}
\hline $\begin{array}{c}\text { The most } \\
\text { common causes of the } \\
\text { employee's dangerous } \\
\text { actions }\end{array}$ & $\begin{array}{c}\text { Groups of causes in accordance with } \\
\text { Mythology }\end{array}$ & $\begin{array}{l}\text { Management tools allowing to minimize the } \\
\text { influence the reasons }\end{array}$ \\
\hline $\begin{array}{l}\text { 1.The low level of } \\
\text { professional competence. } \\
\text { 2. The lack of the } \\
\text { practical experience. } \\
\text { 3.Inefficiency of } \\
\text { training. }\end{array}$ & $\begin{array}{l}\text { A. Can not } \\
\text { The employee does not possess the } \\
\text { necessary knowledge for this work, } \\
\text { relevant skills, methods, techniques } \\
\text { ways of working }\end{array}$ & $\begin{array}{l}\text { 1. Improvement of mentoring. } \\
\text { 2. The use of innovation forms of training, } \\
\text { instruction, control of knowledge and skills. } \\
\text { 3. Improvement of the system of the professional } \\
\text { selection of personnel. }\end{array}$ \\
\hline $\begin{array}{l}\text { 1. Predominance of } \\
\text { penalty elements in the } \\
\text { system of employees' } \\
\text { motivation. } \\
\text { 2. Problems in the } \\
\text { relationship with the } \\
\text { supervisor or co-workers. } \\
\text { 3. Ineffective (excessive } \\
\text { or insufficient) control. }\end{array}$ & $\begin{array}{l}\text { B. Does not want } \\
\text { The employee is able to perform the } \\
\text { work (operation) efficiently and safely, } \\
\text { but he has no desire to follow the } \\
\text { requirements of safety, i.e. absence of } \\
\text { psychological motivation to follow } \\
\text { them. }\end{array}$ & $\begin{array}{l}\text { 1. Actualization and creative rethinking of the } \\
\text { existing system of motivation for the needs of a } \\
\text { particular organization needs. } \\
\text { 2. Identification and promotion of employees with a } \\
\text { high level of motivation. } \\
3 \text { Improvement of the professional personnel } \\
\text { selection system. } \\
\text { 4. Improvement of the system of organization and } \\
\text { payment. }\end{array}$ \\
\hline $\begin{array}{l}\text { 1. Poor health } \\
\text { 2. Adverse emotional and } \\
\text { psychological state of a } \\
\text { person }\end{array}$ & $\begin{array}{l}\text { C. Is not able } \\
\text { The employee is in such physical or } \\
\text { psychological state that despite the } \\
\text { ability and desire acts dangerously. }\end{array}$ & $\begin{array}{l}\text { 1. Improvement of moral- psychological climate in } \\
\text { the team. } \\
\text { 2. Elaboration of measures aimed at preventing such } \\
\text { negative phenomena among co-workers as distress or } \\
\text { professional burnout. } \\
\text { 3. Elaboration of the program of working with the } \\
\text { families of the violators of labour requirements. } \\
\text { 4. Search of the reserves for perfection of labour } \\
\text { organization. } \\
\text { 5. Perfection of the professional personae selection } \\
\text { system. }\end{array}$ \\
\hline $\begin{array}{l}\text { 1. Lack of inadequate } \\
\text { quality of personal } \\
\text { protective equipment. } \\
\text { 2. Imperfection or failure } \\
\text { of the technological } \\
\text { process. } \\
\text { 3. Depreciation of } \\
\text { machinery, equipment } \\
\text { mechanisms. } \\
\text { 4. Lack of or inadequate } \\
\text { quality of tools and } \\
\text { materials. } \\
\text { 5. Adverse working. } \\
\text { 6. Lack of time (hurry) } \\
\text { 7. Lack of the } \\
\text { information about the } \\
\text { organization of work and } \\
\text { changing conditions of } \\
\text { work. }\end{array}$ & $\begin{array}{c}\text { D. Not provided } \\
\text { The employee does not perform the } \\
\text { prescribed action because is not } \\
\text { necessary conditions (tools, materials, } \\
\text { devices, information, etc.) }\end{array}$ & $\begin{array}{l}\text { 1. Search for the reserves to improve the } \\
\text { organization of production and labour. } \\
\text { 2. Perfection of the system of material and technical } \\
\text { support of the enterprise. } \\
\text { 3. Involment (survey) of employees in making } \\
\text { decisions concerning the choice of personal } \\
\text { protection, tools, etc. } \\
\text { 4. Perfection of the effectiveness of the system of } \\
\text { informational support. }\end{array}$ \\
\hline
\end{tabular}


But at forming the effective management influence in the field of industrial safety the peculiarities of the management must be taken into account. The specific aim of managing the system of safe labour is to prevent the reduction of the activity effectiveness that comes from falling of capacity, diseases, traumas and employees death.

The total results from the safety culture are not limited only by reducing injuries. Work in safe conditions improves the employees' moral state that effects productivity.

\section{Successful realization of the management decision}

Management realization is done through the following functions: accounting, analysis and assessment, planning, organization, coordination and regulation, status monitoring, motivation. The composition of management functions at strictly defined management objectives is known: safety measures, account and analysis. Management system must maintain a certain level of safety preventing its decline. The control system must maintain a certain level of security, preventing its loss.

The condition for the successful realization of the management decision is specifying of goals concerning the certain structural subdivision, its quantitative expression, methods of achievement, the involved functions. To determine the impact of the object in the railway structural subdivisions proposed is the research based on Isikava's chart and reasons of industrial traumatism should be highlighted: human factor, influence of environment, organizational, technical and educational reasons (Fig. 2).

The management organ makes decisions taking into account external and internal information. Management functions determine the activity directions at taking decisions on safety labour management. Functions of accounting, analysis and assessment are directed at forming the necessary information about the object of management for the development of management decisions. Certification materials on working conditions, analysis of traumatism and control result are used. etc.

Our research in the railway structural subdivisions confirmed by results of the analysis [3] allowed revealing the following average statistical data of injury causes; $52 \%$ of the total number of injuries are of organizational character, $32 \%$ depend on the human factor, $6 \%$ are of technical and $4 \%$ of training ones. Further is the conclusion that the prevailing part of violations is connected with the human activity (organizational reasons and human factor). Further each of these reasons is subdivided into $5-8$ concrete directions that are estimated in relative terms. After that meaningful management objects are set.

There are some features of the elaboration technology and making the effective management decisions aimed at reducing, industrial traumatism and accident rate in the process of production. The full minimization of risky management functions realization is possible only in the conditions of the definite certainty. We should note that the human factor is the most difficult forecast condition of the management decision realization. Decisions made in risky conditions are the decisions resulting in non-definition but the every possible result can be defined. The management activity in the above-mentioned sphere must be considered as a risk, and efficiency of management decisions should be determined as a possibility of minimization of risks.

On the basis of the study of the modern psychological and normative theories of decisionmaking [5-12] proposed is the technology of work with administrative decisions including the elaboration stage, making and acceptance of decisions. This technology is aimed at minimization of risks related to the accident rate and traumatism.

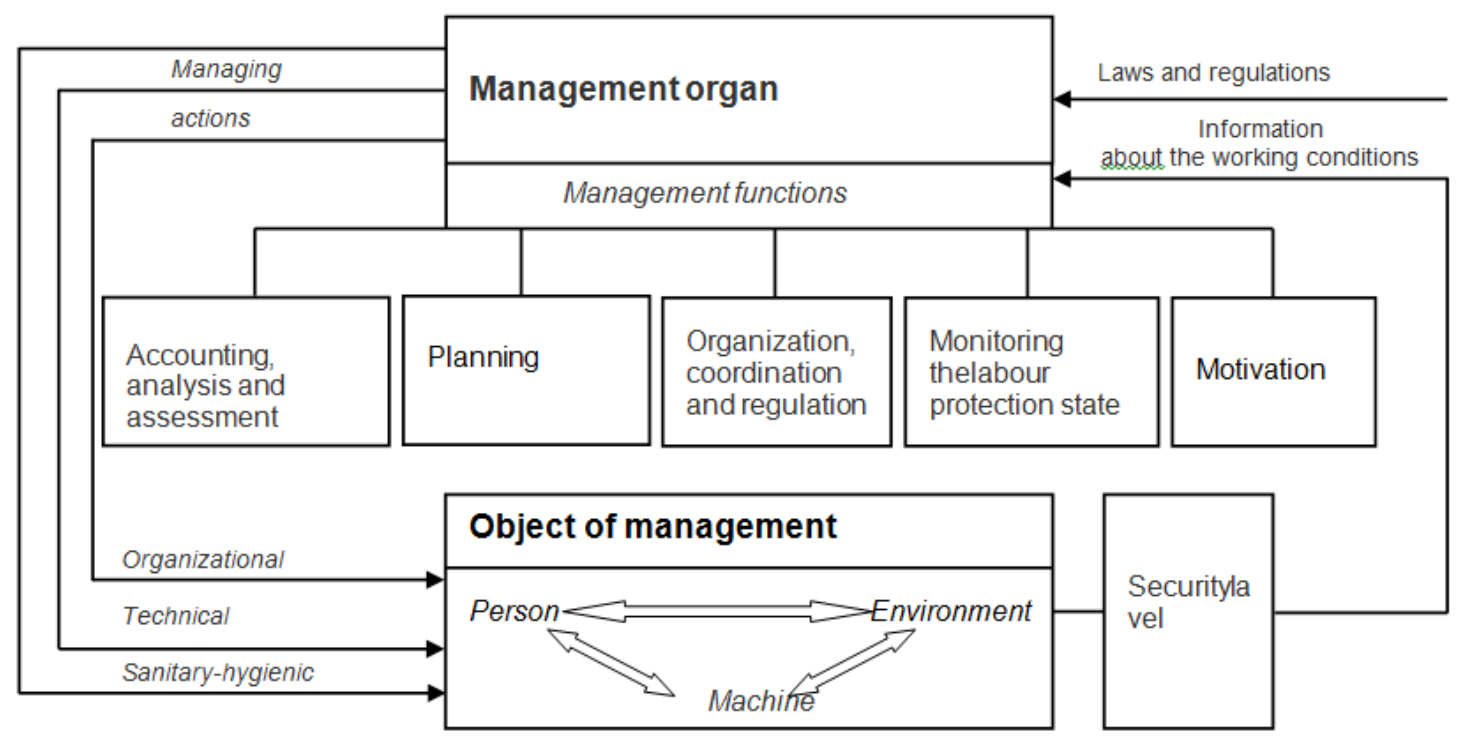

Fig. 2. Functional diagram of safety management. 
When making decisions every variant of development of the events should be estimated as a probability. This allows estimating each of the efficiency value and choosing an option with the variant with a maximum sum of the results based on minimal display of subjective factors.

The results of the research into effectiveness of administrative decision realization show that it can be defined as an integral assessment of the effective implementation of all stages of industrial traumatism reduction level including the degree of risk [12-18].

To expert (qualitative) methods are more often used for the risk assessment, they are based on the subjective assessment of the expected performance parameters [19, 20].

We believe that for the more precise evaluation, quantitative methods of the degree of risk assessment can be appropriately used.

If risks related to various performance aspects and negative factors manifestation occur independently of each other (the rule of mathematical adding of risks), the probability of their manifestation $(\mathrm{Po})$ is estimated by the rules of the probability theory for the probability sum of independent events. For two factors:

$$
P o=p_{1}+p_{2}+p_{1} * p_{2},
$$

and the total measure of risk $(\mathrm{Mp})$ is:

$$
M r=\Sigma\left(p_{i} * P_{i}\right) / \Sigma p_{i}
$$

If the risks related to one performance area and negative factor manifestation occur independently of each other (the rule of risk absorption) the probability of their manifestation is assessed by the maximum value:

$$
P o=\max \left\{p_{i}\right\}
$$

where $P o$ is the overall risk degree in this area; $p_{i}$ is the degree of the particular risks in one area.

The lack of a unified risk management system makes all the particular risks to be considered separately and to use the mathematical rule of their adding.

Implementation of such traumatism management system on an enterprise leads to the possibility of taking them into account in the framework of one type of activity, which means using the risk absorption rule and allows to reduce the overall calculated risk level.

If risks related to various performance aspects, and negative factors are manifested in dependence from one another (the rule of logical adding of risks), the risk is calculated as the sum of the risk of a single event on the other chances:

$$
P o=\Sigma\left(p_{i} * q_{j}\right),
$$

and the total measure of risk $(M p)$ will be:

$$
M p=\max \left\{M p_{i}\right\} .
$$

In other words, the overall measure of risk will be determined by the risk measure of the most risky phase of the project, which means that the level of security of the whole project depends on the degree of risk of injury at each stage. Stage characterized by the least formed injury management system will determine the overall calculated risk level associated with injuries.

The advanced experience of the developed countries shows the monitoring of the process of industrial safety where DuPont $B B C$ program is used. During the research we got an answer of the questioning on the reasons of employees, failures to observe the safety requirements. Then the program allows the typical errors that result in traumas. Thus, the task of BBS is to determine that an employee is in a such condition that will lead to failure and prevent an accident.

The use of the existing works concerning industrial traumatism management allows to effectively dispose the facilities and obtain significant results.

\section{References}

1. B.A. Anfilofyev, E.V. Lukenuk, Y.V. Dementyeva, Vector of Science, TSU, 2(24), (2013)

2. "The methodology for assessing the impact of human factors on the origin of the case injured by the job and determining the percentage of the involved workers," Approved by the order of the open joint-stock company, (2014)

3. S. Young, Management System of an Enterprise: translated from English (Sov. Radio, Moscow, 1972)

4. J. Ober-Krie, Enterprise Management: translated from French (Progress, 1973)

5. V.S. Parshina, Railway Economy, 12, (2008)

6. V.S. Parshina, Railway Economy, 7, (2014)

7. V.M. Ponomaryev, Transport of the Russian Federation, 1, (2011)

8. B.M. Rapoport, Optimization of Management Decisions (Teis, 2001)

9. V.N. Spitsnadel, Theory And Practice Of Optimal Decision Making: textbook (Business Press, St. Petersburg, 2002)

10. Ya.R. Reylyan, Analytical Basis For Decision Making (Finance and Statistics, Moscow, 1989)

11. E.V. Shikhin, A.G. Chkhartashvili, Mathematical Methods And Models In Management (Delo, Moscow, 2009)

12. V.I. Busov, Management Decisions (Yurait, Moscow, 2013)

13. Ye.I. Brazhko, G,V. Serebryakova, V.B. Utkin, Management Decisions (RIOR, Moscow, 2008)

14. A.A. Gusev, USURT Vestnic, 2, 94-103 (2013) 
15. V.N. Kodin, S.V. Lityagina, Work On a Management Decisions (KnoRus, Moscow, 2010)

16. Ye.V. Lavrova, Ye.V. Stroeva, Development Of Managerial Decisions (INFRA-M, Moscow, 2013)

17. V.S. Parshina, A.A. Gusev, Railway Economy, 6, (2013)

18. V.S. Parshina, A.A. Gusev, Innovative Transportation, 5(6), 44-52 (2012)

19. V.A. Trefilov, Safety Management At Work (Health And Safety Measures): textbook (Publishing house of the Perm. state. tehn. Univ., Perm, 2009)

20. N.V. Khokhlov, Risk Management (Unity-Dana, Moscow, 2001)
21. I.K. Adizes, Managing change (Mann, Ivanov and Ferber, Moscow, 2014)

22. A.O. Blinov, Change management: training manual (Dashkov and Ko, Moscow, 2014)

23. W. Bridges, Managing the company through a period of structural (Williams, Moscow, 2008)

24. I. Gerchikova, Management: the textbook (UNITY-DANA, Moscow, 2009)

25. L.D. Gitelman, Transforming management. The leaders of the reorganization and management consultants: a training manual (Delo, Moscow, 1999)

26. A.A. Ogarkov, Management of organization: textbook (Eksmo, Moscow, 2009)

27. A.G. Porshnev, Management organization: textbook (INFRA-M, Moscow, 2008) 